\title{
A meta-analysis on uterine transplantation: Redefining the limits of reproductive surgery
}

\author{
Ana Flávia Garcia Silva ${ }^{1 *}$, luiz Fernando Pina Carvalho ${ }^{2}$ \\ 1BS - Medical Student, Faculdade de Medicina, Universidade de São Paulo (FMUSP), São Paulo, SP, Brazil \\ ${ }^{2}$ PhD - Department of Gynecology and Obstetrics, Hospital das Clínicas, Faculdade de Medicina, Universidade de São Paulo (FMUSP), São Paulo, SP, Brazil
}

\begin{abstract}
SUMmARY
Study conducted at Faculdade de Medicina, Universidade de São Paulo, São Paulo, SP, Brazil

Article received: $5 / 30 / 2015$ Accepted for publication: 6/21/2015

*Correspondence: Address: Rua Oscar Freire, 2121 apto. 1107, Pinheiros São Paulo, SP - Brazil Postal code: 05409-011 ana.flavia.silva@usp.br

In September 2014, the first baby grown in a transplanted uterus was born, which represented an astonishing scientific progress that will mark the history of human reproduction. The recipient was a 32-year-old woman with Rokytanski syndrome who became pregnant after a successful embryo transfer and had an uneventful pregnancy, giving birth to a healthy newborn and marking the beginning of a new era. Patients who do not have a uterus or have a dysfunctional uterus now have the chance of dreaming with pregnancy and motherhood. Combining principles of solid organ transplantation and techniques of human reproduction, uterus transplantation is the first ephemeral transplant performed in order to promote reproductive potential of women and may be removed after successful pregnancy. Worldwide, 11 uterine transplantations were performed in patients. Of these, seven maintained their reproductive potential, with viable transplanted uteri and regular menstrual cycles.
\end{abstract}

Keywords: reproduction, reproductive techniques, transplantation.

\section{INTRODUCTION}

In 2014, the first baby of a transplanted uterus was born, surpassing another limit of reproductive surgery. This was a scientific breakthrough that will be remembered in the history of human reproduction and transform the lives of many women who dream of being a mother. Medically speaking, this would be impossible for patients who were born without a uterus or had them surgically removed. But now, there is hope.

Currently, patients without a uterus or those who have dysfunctional uteri face great difficulties when they wish to become pregnant. The options available include adoption and surrogacy, which are subject to ethical, psychological and legal dilemmas.

In this sense, uterine transplant appears as a revolutionary form of treatment for uterine infertility, which occurs in patients who have severe intrauterine adhesions, those presenting Müllerian anomalies, or who underwent prior hysterectomy. For approximately 9.5 million women in the United States, it is the only treatment option that would allow these patients to experience pregnancy and to give birth to their children. ${ }^{1}$ In Brazil, where about 100,000 hysterectomies are performed annually, ${ }^{2}$ the scenario is similar.
Uterus transplantation consists of a complex treatment that combines principles of solid organ transplantation and assisted reproduction techniques. Furthermore, conducted with the aim of promoting fertility and thus improve the quality of life of the patient, and not necessarily to extend it, this is the first ephemeral transplantation, i.e., the transplanted organ may be removed after the treatment's objectives are achieved. ${ }^{3}$

\section{DeVElopment OF Uterus tRansplantation: Describing the SURGICAL TECHNIQUE}

The donor's surgery begins with a midline incision extending from the navel to the pubic symphysis. Then, the uterus and vascular pedicles are dissected, that is, uterine vessels and a segment of the internal iliac vessels bilaterally. For better fixation in the receiver's pelvis, parts of the round ligament, uterosacral ligament and the peritoneum are also removed. The lateral walls of the pelvis are dissected, and the ureters are completely separated from the cervix and the uterine vessels. The vagina is then dissected 10-15 mm distal to the vaginal fornix. Finally, the vessels are clamped and the blood supply is interrupted. Then, the uterus is removed and transported to the 
table, where it is initially flushed with heparinized saline solution, followed by cold preservation solution. The uterus is kept on ice until the time of transplantation. ${ }^{4}$

Likewise, the receiver's surgery begins with a subumbilical midline incision. First, the vaginal walls are separated from the bladder and rectum, and sutures are attached to the round ligament, uterosacral ligament, uterine rudiment (patients with Müllerian anomaly), or paravaginal connective tissue (patients with cervical cancer) for later transplant fixation. The external iliac vessels are then dissected bilaterally. The uterus is brought into the room, still on ice, and placed in the receiver's pelvis in an anatomical position. End-to-side vascular anastomoses are performed between the vessels of the graft and the external iliac vessels, after which the clamping of the external iliac vein is released. A mannitol intravenous bolus is administered immediately before the arterial clamping is released, and the systolic blood pressure is monitored and maintained above $100 \mathrm{mmHg}$. After completion of all vascular anastomoses, blood flow in uterine vessels is quantified using a Doppler probe placed around the uterine arteries. ${ }^{4}$
The receiver's vaginal walls are opened using a longitudinal $40 \mathrm{~mm}$ incision, and the vaginal portion of the graft is anastomosed to the Douglas' cul-de-sac. The uterus is fixed in anatomical position by binding of the sutures pre-positioned to their respective ligaments, and by superimposing the graft's peritoneum on the recipient's bladder. ${ }^{4}$

The receiver's anesthesia and surgery are, in general, identical to the donor's. The pre-transplant evaluation of patients has been extensively described for solid organ transplantation. The standard protocol published in immunosuppression literature consists of a triple regimen of tacrolimus, azathioprine and corticosteroids, which appears to be safe during pregnancy. The cases of mild rejection were successfully treated with pulse steroid therapy. ${ }^{4}$

\section{Results}

Worldwide, 11 uterine transplantations were performed in patients (Figure 1). In 2000, the first case of uterine transplant was performed in Saudi Arabia in a 26 year-old patient with a history of hysterectomy due to postpartum hemorrhage, who received the organ from a liv-

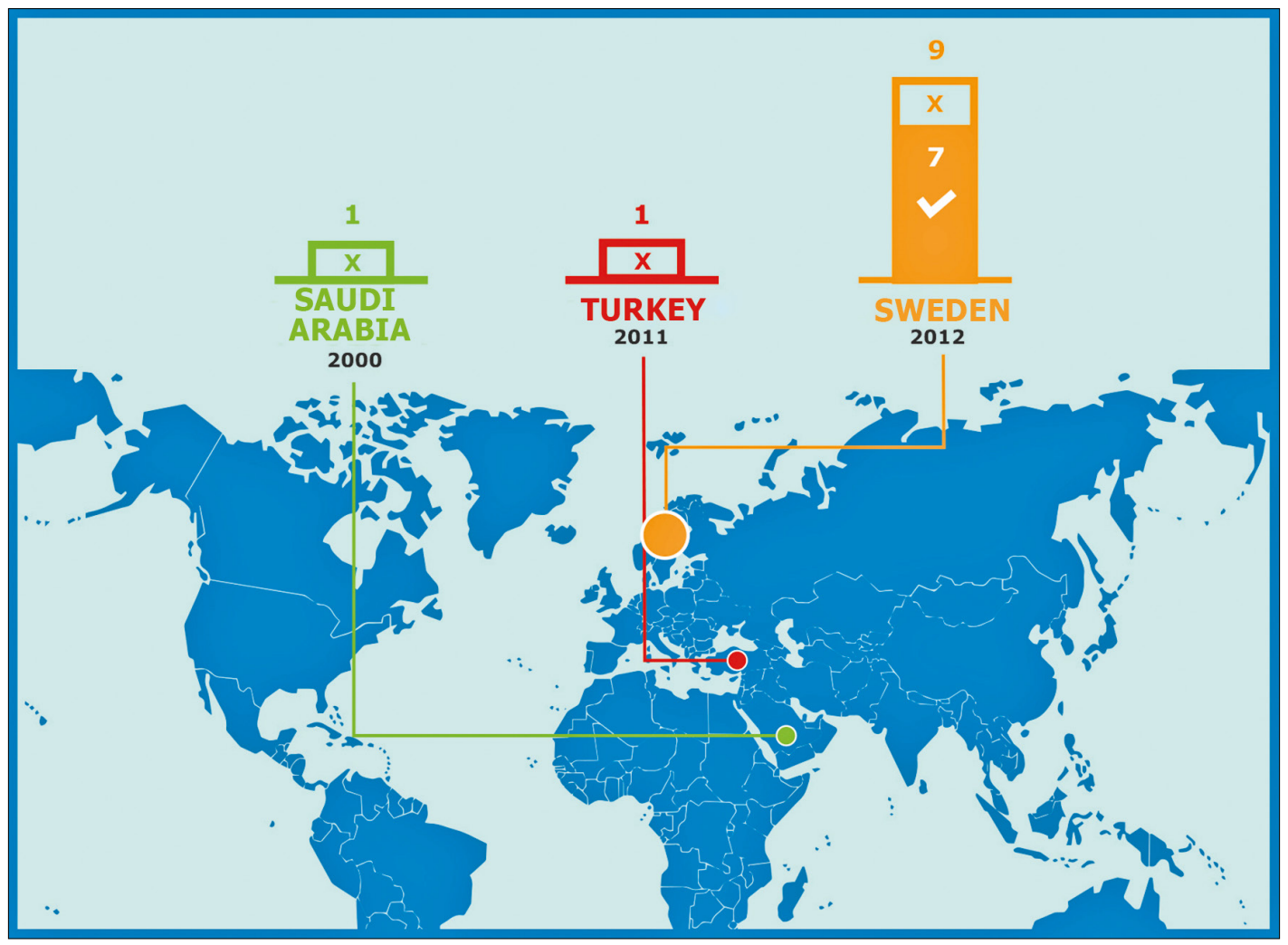

FIGURE 1 On the map, the three centers performing uterus transplantation in humans in the world: Saudi Arabia (N=1) in 2000, Turkey $(\mathrm{N}=1)$ in 2011, and Sweden ( $N=9)$ since 2012.

$X$ : Transplant with complications leading to hysterectomy; $\checkmark$ : Transplants that maintain reproductive potential. 
ing donor. Three months after transplantation, the transplanted uterus developed progressive necrosis, and hysterectomy was performed. ${ }^{5}$ The second case occurred in 2011 in Turkey, in a patient with Rokytanski syndrome who received the organ from a deceased donor. The transplanted uterus was viable and the patient underwent embryo transfer 18 months after the operation, having presented two pregnancies spontaneously aborted before 6 weeks of gestational age (GA). ${ }^{6}$

Initiated in 2012 in Sweden by the group of Dr. Brannstrom, the clinical trial on uterus transplant was responsible for the following nine cases in which nine patients, eight suffering from Rokytanski syndrome and one with prior hysterectomy due to cervical cancer, received transplants from living donors. Two patients underwent hysterectomy during the first few months after transplantation due to uterine artery thrombosis and severe intrauterine infection, respectively. The remaining seven patients started to have menstrual cycles about 2 to 3 months after transplantation, and maintained regular menstrual cycles during the first year. Transplants remained viable and, to date, the seven patients have reproductive potential (Table 1). ${ }^{4}$

One of the cases in the clinical trial, a 35 year-old patient with Rokytanski syndrome that in 2013 received the uterus of a donor aged 61, resulted in pregnancy and in the first baby born after uterus transplantation and successful embryo transfer. The transplanted uterus had only one episode of mild rejection, reversed by corticosteroids. Pregnancy had no complications, with a benign fetal evaluation and uneventful throughout pregnancy. The patient was admitted with preeclampsia at 31 weeks and 5 days, and cesarean delivery was performed. A newborn with normal weight for gestational age and Apgar scores 9, 9, 10 was born in September 2014. ${ }^{3}$

\section{Conclusion}

After 15 years of research, the first baby resulting from a transplanted uterus was born in 2014. Uterus transplantation is a revolutionary new option for patients with uterine infertility, most commonly caused by Rokytanski syndrome, previous hysterectomy, or severe intrauterine adhesions. It is the only treatment that enables the experience of pregnancy for women with such conditions. Since this is still an experimental procedure, the risks and benefits, as well as medical and legal complexities should be discussed regarding the three parties involved: the donor, the recipient and the fetus. Possible complications include rejection, infection and necrosis of transplanted uterus, and need for hysterectomy may occur. These complications can be especially critical if they occur during pregnancy, and should be addressed in the preoperative counseling.

Furthermore, since the surgery involves section of pelvic nerves, it is unclear how the pregnancy will be experienced by the recipient, since many sensations of pregnancy and labor may be perceived differently. ${ }^{7}$ Thus, the case of the aforementioned patient will be valuable, although a greater number of cases is necessary for better understanding of the perinatal period.

The limited number of transplants performed does not allow the conclusion that there are differences in results depending on donor modality: deceased or living, family or non-family. As for the immunosuppressive ther-

\section{TABLE 1 Data of 11 cases of uterus transplant performed.}

\begin{tabular}{|c|c|c|c|c|c|}
\hline Date & Country & $\begin{array}{l}\text { Receiver's } \\
\text { condition }\end{array}$ & $\begin{array}{l}\text { Donor } \\
\text { modality }\end{array}$ & Complications & Results \\
\hline 2000 & $\begin{array}{l}\text { Saudi Arabia } \\
(\mathrm{N}=1)\end{array}$ & $\begin{array}{l}\text { Hysterectomy due to } \\
\text { postpartum } \\
\text { hemorrhage }\end{array}$ & Living donor & Progressive uterine necrosis & $\begin{array}{l}\text { Uterus viable for } 99 \text { days, during } \\
\text { which the patient had two menstrual } \\
\text { cycles }\end{array}$ \\
\hline 2011 & Turkey $(\mathrm{N}=1)$ & Rokytanski syndrome & Deceased & No complications & $\begin{array}{l}\text { Two pregnancies with spontaneous } \\
\text { abortion before the sixth week of } \\
\text { gestation }\end{array}$ \\
\hline $\begin{array}{l}2012- \\
\text {-current }\end{array}$ & Sweden $(N=9)$ & $\begin{array}{l}\text { Rokytanski syndrome } \\
(\mathrm{N}=8) \\
\text { Hysterectomy due to } \\
\text { cervical cancer }(\mathrm{N}=1)\end{array}$ & Living donor & $\begin{array}{l}\text { Uterine artery thrombosis } \\
(\mathrm{N}=1) \\
\text { Severe uterine infarction } \\
(\mathrm{N}=1) \\
\text { Episodes of mild rejection } \\
\text { successfully treated with } \\
\text { corticosteroids }(\mathrm{N}=4)\end{array}$ & $\begin{array}{l}\text { Seven cases: Uterus viable in the late } \\
\text { postoperative period, with } \\
\text { reproductive potential } \\
\text { *In September } 2014 \text {, the first baby of } \\
\text { a transplanted uterus patient was } \\
\text { born }\end{array}$ \\
\hline
\end{tabular}


apy, the method used has been described as safe and nonteratogenic in other solid organ transplants. ${ }^{8}$

It is noteworthy that, unlike with other organs, uterine transplant is an ephemeral transplantation performed with the aim of promoting quality of life for patients, not to prolong survival. Thus, the institutional research committee protocol recommends the removal of the uterus transplanted after two pregnancies in order to avoid long term immunosuppression and complications. ${ }^{3}$ However, this is the patient's decision. In the coming years we should learn from studies in progress regarding follow-up of transplanted patients and long-term results of maintained immunosuppression and graft and reproductive success.

Effectively, uterus transplantation is an option that redefines the boundaries of reproductive surgery, offering new horizons for patients without a uterus or with a dysfunctional uterus, and who recently began to dream about the possibility of giving birth and becoming mothers.

\section{Resumo}

Uma metanálise sobre o transplante de útero: redefinindo os limites da cirurgia reprodutiva

Em 2014, nasce o primeiro bebê oriundo de um útero transplantado, um avanço científico que ficará marcado na história da reprodução humana. A paciente, portadora da síndrome de Rokytanski, engravidou após transplante de útero e transferência de embrião. Teve uma gestação sem complicações e deu à luz um recém-nascido saudável, marcando o início de uma nova realidade. Pa- cientes que não possuem útero ou possuem útero disfuncional agora podem sonhar em ser mães e gestar um filho. Combinando princípios de transplante de órgão sólido e técnicas de reprodução humana, o transplante de útero consiste no primeiro transplante efêmero realizado com o intuito de promover potencial reprodutivo à mulher, podendo ser removido após gestação bem-sucedida. Mundialmente, 11 transplantes de útero foram realizados em humanos. Dentre os casos, sete mantêm potencial reprodutivo, com úteros viáveis e ciclos menstruais regulares.

Palavras-chave: reprodução, técnicas reprodutivas, transplante.

\section{REFERENCES}

1. Arora KS, Blake V. Uterus transplantation: ethical and regulatory challenges. J Med Ethics. 2014; 40(6):396-400.

2. Brasil. Ministério da Saúde. DATASUS [Internet]. Sistema de Informações Hospitalares do SUS: Banco de Dados. Brasília (DF): Ministério da Saúde; 2015 [cited 2015 Apr 5]. Available from: http://www.datasus.gov.br.

3. Brännström M, Johannesson L, Bokström H, Kvarnström N, Mölne J, DahmKähler P, et al. Livebirth after uterus transplantation. Lancet. 2015; 385(9968):607-16.

4. Brännström M, Johannesson L, Dahm-Kähler P, Enskog A, Mölne J Kvarnström N, et al. First clinical uterus transplantation trial: a six-month report. Fertil Steril. 2014; 101(5):1228-36.

5. Fageeh W, Raffa H, Jabbad H, Marzouki A. Transplantation of the human uterus. Int J Gynaecol Obstet. 2002; 76(3):245-51.

6. Erman Akar M, Ozkan O, Aydinuraz B, Dirican K, Cincik M, Mendilcioglu I, et al. Clinical pregnancy after uterus transplantation. Fertil Steril. 2013; 100(5):1358-63

7. Arora KS, Blake V. Uterus transplantation: the ethics of moving the womb. Obstet Gynecol. 2015; 125(4):971-4.

8. Brännström M, Almén Wranning C, Marcickiewicz J, Enskog A, Hanafy A. Uterus transplantation-substantial progress in research but not yet ready for the clinic. Middle East Fertil Soc J. 2007; 12(2):86-95. 